\title{
Media, Politics and Gender Marginalisation in Nigeria: Is There Still a Way Out?
}

\author{
Oyewole, John Ayodele \\ Olisa, Damilola Saheed
}

Department of Mass Communication, Adekunle Ajasin University, Akungba-Akoko, Ondo State, Nigeria

\begin{abstract}
Previous research in the area of media, politics and female communication suggests that women are generally marginalised in Nigerian polity, making the polity excessively male-dominated. This paper therefore seeks to provide way out of the prolonged debate on gender marginalisation and inequality to safely ascertain ways for active female representation. Based on secondary sources available, this discourse examined factors limiting female representation especially media-related factors; inadequate media attention during election campaign, discriminatory religious doctrines, media bias and portrayal, male dominance amongst others. In providing answers to the question raised in the title of the discourse, the paper recommended increased media attention and portrayal, media mobilisation and education on female rights, improved women emancipation programmes as part of ways out of gender marginalisation in Nigeria.
\end{abstract}

Keywords: Media, Marginalization, Politics, Representation

\section{INTRODUCTION}

Are women still really involved in politics? Do they still occupy any electoral positions? Are the media helping to salvage this situation? These and many more questions have received considerable attention from various studies and discourses across the world, championing the call for women involvement in politics and governance. Despite these numerous scholarly agitations, it is very unclear where there is still a way out of the murky gender battle of relegating women to the supportive roles in political and leadership matters. However, in every democratic state or nation, the relation between the society, media, governance and politics cannot be over emphasised because the media are a representation of the kind of society in which it finds itself (normative theory) and are capable of correcting ills of such society when the need arises (libertarian theory). No doubts, the media constitute a major player in the portrayal and election of any government which is representative of the people. Hence the mass media generally have been identified as a major component wielding so much power as strong and influential roles in the society. The mass media, whether print or broadcast forms, perform these functions through their traditional roles as identified by Harold Lasswell; information function, editorial function and agenda-setting function.

Towards expressing this fact, Egbon (2007, p.56) notes that:

The press possesses the potential power to influence, not only the people, but also the society as a whole, and this influence can be for the political, socio-cultural and economic good or to the detriment of the country and by logical progression, this could extend to global issues and actions of great concern and magnitude.

However, in the case of media representation of females in Nigerian politics, the media have scored below average, relegating women to supporting roles in politics and leadership. This form of mediasponsored gender politics has led to the polarisation of Nigeria into two camps: those seeking to maintain societal tradition and those seeking to dismantle the patriarchy structure of the society (Oyinade, Daramola and Lamidi, 2013).

A quick scan of various studies carried out in the area of media, politics and gender marginalisation in Nigeria (Enwefah, 2016; Oyesomi and Oyero, 2012; Oyinade, Daramola and Lamidi, 2013) have 
proven that the Nigerian media have not done so much in salvaging the current situations of gender marginalisation in Nigerian politics, rather the media have over the years reflected its male-dominated reportorial world (Enwefah, 2016). Based on these studies that have been carried, it is apt to say that media representation of women is contentious. Therefore, this paper debates whether there is a still a way out of media misrepresentation of women in politics, identifies the possible causes of these marginalization and possible solutions to it.

\section{BaCKground to Media/Politics/Gender Marginalisation in Nigeria}

It is arguable that before the advent of colonial administration in Nigeria, women had the opportunity to play prominent and active roles in the affairs of traditional political governance (Akinboye, 2004), but the advent of colonial era brought about increased marginalisation and male dominance in Nigerian governance. Examples of women who played active role during the pre-colonial era include Queen Amina of Zaria who was regarded as a fierce warrior and conquered many states during the $14^{\text {th }}$ century, Iyalode Efunsetan Aniwura of Ibadan, Moremi of Ife Kingdom, Inikpi of Igalaland, Emotan and Idia of Benin Kingdom, Omu Okwel of the Ossomari Kingdom. These women have come to be regarded as reckoning forces that wielded huge political influence during the pre-colonial era.

Akinboye (2004) however notes the advent of colonial administration led to "gender policies, economic interests, and generalized patriarchal values that reinforced and perpetuated gender inequality in the country."'This was evident in the 1922 Clifford Constitution which allowed for election of Nigerians into legislative positions, but however excluded women from being voted for. The first generation of political parties were obviously dominated by males. Of all the three legislative seats allocated to Nigerian in the legislative council in 1922, no woman was able to occupy any of the seats. Ajayi (2007) posits that "these practices notably signified the beginning of masculinity of politics and women's alienation from the mainstream Nigeria's politics."

Even in recent times, this form of marginalisation has continued. The 2015 presidential election did not in any way salvage the disproportional representation of women in Nigerian politics. At the presidential level, Independent National Electoral Commission (INEC) cleared 14 candidates, with 13 being men and 1 woman. Professor Comfort Oluremi Sonaiya of KOWAwas the only female presidential aspirant. Among the vice-presidential aspirants, there were 10 men and 4 women. The female vice presidential aspirants were Anthony Faith Ologbosere of African Peoples Alliance (APA), Hassana Hassan of the Congress for Progressive Change (CPC) and Arabamhen Mary of the Peoples Party of Nigeria (PPN).

Sonaiya, who emerged winner out of 3 other men at the KOWA presidential primaries, was the first woman to ever qualify as a presidential candidate in Nigeria. The results of the presidential election revealed that the number of votes she was able to secure was greater than some other candidates. The total number of votes she gathered surpassed that of HOPE Democratic Party (HDP) and United Democratic Party (UDP) parties during the election. While the total number of votes for HOPE was 7,393 and UDP was 9,147 votes, KOWA party had 12,524 votes (Olalere, 2015).

In a study conducted on newspaper coverage of women's participation in the 2011 general elections in Nigeria by Oyesomi and Oyero (2012), they found out that the Nigerian newspapers particularly; The Punch and The Guardian did not give adequate coverage to reportage on women participation in the election compared to their male counterparts. Of the 464 stories that were content analysed in the study, only 62 reports were centred on women participation. In the 2011 general elections, women participation accounted for mere $9.1 \%$ in the general election which comprised presidential, gubernatorial and legislative elections.

Since the advent of the libertarian media theory, the media have been classified as one of the main components of any society, acting as an active force in determining and shaping public beliefs and perceptions towards issues, thereby enjoying power of socialization, mass mobilization and advocacy. This power of the Nigerian media is obviously being misused or underused in the area of media representation of female political candidates in Nigerian politics. Endong and Obonganwan (2015, p.102) affirm this stance by accusing Nigerian media of "misrepresenting the woman folk." They added that the media "utterly trivialize or relegate women to secondary and inferior positions in the society." 
In their book, Kovach and Rosentiel (2001) itemised the nine principles of journalism with the first being obligation to the truth, that is, the first duty of the media of any society to the citizens. Other duties as cited in Oyinade, Daramola and Lamidi (2012, p.30) include:

Its essence is a discipline of verification, its practitioners must maintain independence from those they cover, serve as an independent monitor of power, provide forum for public criticism and compromise, strive to make the significant interesting relevant, keep the news comprehensive nod proportional, and that practitioners must be allowed to exercise their personal conscience.

A cursory look at these principles shows the media owes as a duty of care to properly represent the neglected section of the society. In addition to this stance, the United Nations' Report on African women in 1995 notes that the media also help to accentuate gender inequality through stereotypic reports and negative portrayal of women.

In fact, the situation has degenerated up to the stage where the media are embroiledin gender marginalisation as the newsrooms of most media outfits are filled with male practitioners, leaving women to occupy supportive positions. In a content analysis study of gender representations in Nigerian newspapers by Enwefah (2016), it was discovered that there is huge male domination of the editorial and reportorial units of Nigerian newspapers. This representation replicates the form of maledominated reports that fill the Nigerian media, putting women to the rear. The American Society of Newspaper Editors (ASNE, 2005) also justifies this by adding that around65.2 \%of newsroom supervisors are male, while $34.8 \%$ are female, only a shift improvement for women since 1999 (ASNE, 1999).

\section{Media Framing ANd Gender MARginalisation}

This history of media framing analysis is often traced to Erving Goffman in his foremost work entitled "Framing analysis: An essay on the organisation of experience" in 1974. Framing is one of the media effects theories, largely used to analyze how the mass-media filter information and, thus, influence public reactions to a whole range of external stimuli (De Vreese, 2007).Under the framing theory, the media have the ability to promote a particular news item through measures or techniques such as selection, emphasis, exclusion, and elaboration (Scheufele \& Iyengar, 2010). The theory further states that it provides the justification for which journalists shape or report an issue in a particular way.

McQuail (2005) cited in Olisa (2015) posits that there are two ways via which media framing can be studied in communication research; individual frames and media frames. The individual frame deals with an individual's cognition or understanding of a given situation. The individual frame is often attached to Goffman's (1974) study on framing.

On the other hand, media frame, which is of more interest to this discourse, has to do with presentation styles, images and dictions employed by a media outfit and the perception of that media outfit about a particular issue. Similarly, the media frames serve as working routines for journalists that allow the journalists to quickly identify and classify information and to package it for efficient relay to their audiences (Scheufele, 1999).

From Entman's (1993, p.52) perception of media framing, "to frame is to select some aspects of a perceived reality and make them more salient in a communicating text, in such a way as to promote a particular problem definition, causal interpretation, moral evaluation, and/or treatment recommenddation." From Entman's viewpoint, it can be simply put forward that, media framing is the method via which promote some certain aspects of the news by using methods such as selection, emphasis and elaboration. In this sense, these frames are the tools or methods used by journalists in projecting issues to the public. In relation to media framing of women in politics, Tuchman (1978) uses the term "symbolic annihilation" to describe "the media's condemnation, trivialization and omission of women", representing women through a gendered lens of sex roles.

\section{Gender Marginalization: Propelling Factors}

Numerous studies in the area of female representation in election campaign in Nigeria have proven beyond doubts that the Nigerian media do not provide adequate attention to the reportage of election campaign by the few female candidates who contest in these elections. This issue has qualified for drastic alert by media owners and proprietors to provide adequate space or airtime to female political candidates despite the low budgets of these candidates. Media proprietors are generally known to be profit-oriented and will be willing to provide broadcast airtime or newspaper space which is always 
very competitive during election campaigns to candidates with lucrative offers. As a result, inadequate media attention qualifies as a factor for gender inequality in Nigerian politics.

In a study conducted on newspaper reportage of gender inequality by Nigerian media, Oyinade, Daramola and Lamidi (2003) found that the newspapers that were randomly selected provided only pictures about female-related stories without any details to explain reason for which such pictures were taken. Another instance of inadequate media attention was in the case of Hon. Barrister (Mrs.) Ugochi Nnanna-Okoro, politician and former Peoples Democratic Party governorship aspirant in Imo state in 2003 general elections who was out rightly denied access to campaign on the state's radio station on the ground that she did not get approval from the state government. Nwankwo (2005, p.288) notes thus:

Ugochi was shocked to find her access to state-owned Radio and Television Stations blocked. Money she paid for publicity was returned to her 'on the pretext that I failed to get approval from the Imo State Government, Also at the Imo Broadcasting service, some retorted, 'Madam take back your money. I don't want to be sacked' she said.

Meanwhile, in most Nigerian cultures, males are often respected and expected to be leaders of the home and society at large. This mind-set is also transferred into politics and governance in the sense that it is unconsciously written in the heart of people that women are expected to take supporting roles in politics, limiting women's ability to contest for electoral positions. Similarly, this male chauvinist attitude has been indoctrinated into family values through giving male children higher status and responsibilities compared to the female child. The female child grows up with this mindset of her counterpart being eligible to take higher responsibility in the society.

Okuna (2002) affirms this male dominance by saying that

Gender relations in Nigeria are characterized by a lot of imbalance, to the disadvantage of women. This is the twenty-first century, yet tradition, culture, religion and other factors have continued to widen the disparity between Nigerian men and women, by keeping women in a subordinate position to men.

In addition to Okunna's position, it can be argued that the mass media are also contributing to this patriarchy in Nigerian society through their reports which are excessively male dominated despite Nigeria's 50\% female population. Citing GMMP (2000), Okunna (2002) stresses that the $91 \%$ of journalists whose by-lines appear in magazines is male, while a staggering figure of $86 \%$ of people who appear in the news is male. These figures lend to the fact that media portrayal of male dominance contribute to gender marginalisation in Nigeria's politics.

Closely tied to maledominance are discriminatory customs and traditions. It is no doubt that majority of African customs and norms are construed to frame women generally as "weaker sexes", thereby playing supportive roles to their male counterparts. The overall practices of norms, cultures and belief systems have allowed for general subjugation of women to men in political and administrative functions, even traditional functions, thereby preventing women from championing or showing interesting in picking leadership positions. Agbalajobi (2009) agrees to this stereotypic bias by citing the example of how mist customs prefer sending their male child to school over the female child as female education is often seen as waste because of the domestic duties women end up being occupied with later in life.

Pollos Bitros in article cited by Oyinade, Daramola and Lamidi (2013, p.27), he sums up the issue of customary sentiments thus:

In Nigeria situation, a lot of historical, social researchers conducted, indicated that women's place is in the home. Right from childhood, children (male and female) are taught to keep the roles associated with their sexes. It must be noted that a boy must not be taught how to cook in the kitchen except after his seem day education he may be interested in catering studies as a profession.

Another factor worth considering is constitutional provisions and impediments to female representation in politics. Although the Nigerian 1999 constitution allowed for female candidates to contest any political positions of their choices, yet there are still some constitutional impediments restraining female representation in Nigerian politics. Sections 5 and 40 of the 1999 constitution of Nigeria both guaranteed Nigerians, either male or female, political rights to vote and be voted for. Section 40 of the constitution (CFRN, 1999) states thus; 
Every person shall be entitled to assemble freely and associate with other persons, and in particular he may form or belong to any political party, trade union or any other association for the protection of his interests: Provided that the provisions of this section shall not derogate from the powers conferred by this Constitution on the Independent National Electoral Commission with respect to political parties to which that Commission does not accord recognition.

Despite this stipulation, the constitution seems murky in the area of ensuring political participation for married women in terms of constituency representation. Quoting Olufemi (2006), Ugwuegede (2014) explains that:

Married women are often confronted with the problem of constituency, especially if they are married outside her locality or state of origin as she cannot claim the state of origin of her husband. If a married Nigerian woman goes back to her constituency orbirth/stateof origin, she is likely to receive the same discriminatory treatment for she regarded as being over ambitious and a "non-indigene" by her own state of origin.

Similarly, the constitution can also be criticised for not being explicit and direct in ensuring equal representation on sexual bases, unlike the constitution of other notable countries like South Africa and Uganda (Agbalajobi, 2010).

Furthermore, discriminatory religious doctrines are other factors contributing to gender marginalization in Nigeria. It is very disappointing that majority of Nigerians in the $21^{\text {st }}$ century still hold tenaciously to religious doctrines that obviously deny women equal representation in the social and project women as more of helpers to their male counterparts. In Christianity, women are often restricted from taking even religious leadership and this orientation is replicated in other spheres of life. The creation story among Christians and other bible sources portrayal male patriarchy in a positive light, leaving women to a disadvantaged background. Similarly, Islam too does not favour female representation in leadership positions as women are seen as supportive and subject to their husbands at all times.

\section{WAY FORWARD FOR FEMALE REPRESENTATION}

An expedient factor in tackling gender discrimination in Nigerian politics has increased media attention and positive portrayal of female political candidates during political campaign. Various studies which have been conducted in this field point to the same direction of inadequate and negative portrayal of female candidates, which prevents them from getting enough political participation. The media, according to the Libertarian theory of the press, are expected to provide a level playing for different people and a market place of ideas.

Instead of providing adequate support for female candidates through media attention and portrayal, Nigerian media often down-played or do not mention achievements of women in the past. Ashimi (2008) agrees to this position by saying thus: "the ability of the media to make or mar the image of women in the society cannot be denied or underestimated. In fact, the United Nations document recognising the media as a critical area for women listed the media as one of the ten obstacles to women advancement." By inference, the media are major agenda setters in effectively portraying female representation in positive light to the public. Similarly Zhu and Blood (1997) in Olisa (2015) attest to this media agenda setting power by the media signal the importance of certain issues by giving these issues preferential treatment, such as more frequent coverage and more prominent positions. Also, the responsibility lies of media players and proprietors to ensure that journalists are properly trained regularly in journalism practices, including the use of appropriate frames and media tools in portraying issues or group of people. This is needed because the advent of online journalism has birthed the prevalence of "mushroom journalism"- a form of journalism where timely reportage of events (that is, timeliness) is prioritised over details or appropriate representation of issues or people in the news. Gallagher (2001, p.172) attests to the problem of this journalism thus:

One of the problems is that in the media, as in every sector, the accepted way of doing things is usually also the easiest. The challenge for the activists is to convince media professionals that the easiest way is not necessarily the best - in terms of the quality of their output, or its appeal to the audience.

Meanwhile, before there can be adequate representation of female participation in the media, there is a need for adequate representation of women in Nigerian media. Several studies conducted in this area 
(for instance, Enwefah, 2016) have agreed that there is inadequate representation of women in the editorial and reportorial staff of Nigerian newspapers. Hence, media houses in Nigeria need to increase the number of female staff they have. Even wealthy women should go into owing media platforms for proper portrayal of female participation in politics.

In addition to positive portrayal, media mobilisation and education on female rights towards the publics are part of activities to salvage the gender inequality situation. This is so because customs and traditions are part of the major causes of inadequate female representation in Nigerian politics and the media is in best place to counter these anti-female beliefs, customs and traditions through effective mobilisation and education on female representation in Nigerian politics. Mass advocacy in form of campaigns, adverts, opinion articles and programmes are instrumental to educating and re-orientating Nigerian populace on the relevance of gender equality and female representation in politics. These customs which need to be erased have over the years indoctrinated Nigerians and Africans at all to believe that women are naturally meant to take supportive roles in public offices and they should be limited to mainly culinary activities. Through proper media education, women can be motivated to take up higher positions without having to settle for supportive or assistant roles.

Aside the media duties in tackling gender marginalisation, enshrinement of female representation in Nigerian laws and customs constitutes a lot in winning the battle against gender marginalisation. Considering the developing nature of Nigeria in terms of female representation, there is a need for the enshrinement of adequate female representation in terms of quotas in the Nigerian constitution and laws as financial, cultural, political and traditional factors constitute factors that limit female representation. Apart from the general the basis of sex etc, there is nothing in the constitution that is aimed at redressing the disparities that exist along gender lines in Nigeria (Agbalajobi, 2010). Nigeria, unlike some notable African countries such as South Afrcia and Ugnada did not take adequate cognizance of female representation and as a result did not make provision for gender equality (Agbalajobi, 2010). In a nutshell, there is the urgent need for the proper enshrinement of female representation in the Nigerian written laws in order to eliminate gender marginalization in the country. However, there is still the need for improved and widespread programmes from the bodies in order to achieve greater results. Sand Brook and Halfari in (Agbalajobi, 2010, p.80) defined women empowerment thus:

a multi-dimensional process involving the transformation of the economical, political, social, psychological and legal circumstances of the powerless with its aim of dismantling the cultural, traditional and social norms, which disvalue, disempower and dispossess women with its central objectives tied to the needs of women to opportunities,

facilities, skill acquisition and position of authority, especially within the political sphere.

One of such forums which should pay considerable attention to matters of female representation is Forum of Nigerian Women in Politics (FONWIP) through regular organisation of seminars and lectures even to populace at the grassroots level which really require re-orientation on the their knowledge of female leadership in general and even female violence. Similarly, groups such as FONWIP should ensure the Nigerian government implement equal representation at every level of government starting from the local government level up to the federal government.

\section{Conclusion}

Countries of the world have continued to increase their level of female participation in politics and leadership, encouraging women to engage actively in politics and providing enabling platforms for women to engage in politics through active and proper media representation of women in diverse forms of media contents. However, this situation has not been on the rise in Nigeria as women are still left behind in political engagements. Hence, it is very necessary and relevant for Nigeria to increase its level of female participation in politics and to do this, the Nigerian media has an active role to play towards re-orientating Nigerians on the need for gender balance in politics.

\section{REFERENCES}

Agbalajobi, D.T. (2010). Women's participation and the political process in Nigeria: Problems and prospects. African Journal of Political Science and International Relations, 4(2), 72-82.

Akinboye, S. (2004). Challenges and prognosis of gender equality in Nigerian politics. In Akinboye (ed.) Paradox of gender equality in Nigerian politics. Lagos: Concept Publications.

Ajayi, K. (2007). Gender self-endangering: The sexist issue in Nigerian politics. Journal of Social Sciences, 14(2), 137-147. 
Ashimi, 0. (2008). Portrayal of women entrepreneurs in the Nigerian press: A study of the Guardian \& Financial Standard newspaper. Unpublished B. Sc. Graduation project, Covenant University. Ota

Dahl, R. (1971) Polyarchy: Participation and Opposition. New Haven: Connecticut: Yale University Press.

Egbon, M. (2007). Problems of ethics in the mass media. In The line editor as gatekeeper. Lagos: Nigeria Press Council. pp. 81-88.

Enwefah, C. (2016). Gender representation in the editorial and reportorial staff of newspapers in Nigeria. Global Journal of Human-Social Science: Arts \& Humanities - Psychology, 16(1), pp. $1-7$

Federal Republic of Nigeria (1999). Constitution of the federal republic of Nigeria. Abuja: FRN.

Gallagher, M. (2001). Gender setting: New agendas for media monitoring and advocacy. London: Zed Books in association with WACC.

Momoh, A. and Adejumobi, S. (1999). "The Nigerian military and the crisis of democratic transition." In Okpaga, A. (ed.). The electoral journal, 1(1), p. 48

Ngara, C and Ayabam, A. (2013). Women in politics and decision-making in Nigeria: Challenges and prospects. European Journal of Business and Social Sciences, Vol. 2, No.8, pp 47-58.

Nnadozie, U.O. (2004). "History of elections in Nigeria." A paper presented at the 2004 annual conference of the national political science association held at Abuja between June 27-30.

Okoro, N. and Odoemelam, C. (2013). "Print media framing of boko haram insurgency in Nigeria: a content analytical study of the Guardian, Daily Sun, Vanguard and This day Newspapers," Research on humanities and social Sciences, 3(11), 86-94

Olalere, T. (2015). Women and Nigerian Politics: An Appraisal of 2015 General Elections. Conference Paper delivered at INEC

Olisa, D. (2015). Newspaper framing of the APC change campaigns in the 2015 presidential election: A study of The Punch and The Guardian newspapers. Unpublished research project submitted to the Department of Mass Communication, Adekunle Ajasin University, Akungba-Akoko.

Oyesomi, K. and Oyero, O. (2012). Newspaper Coverage of Women's Participation in the 2011 General Elections in Nigeria. The Journal of The African Council for Communication Education, 10(1), 136-156

Oyinade, B., Daramola, I. and Lamidi, I. (2013). Gender, media and politics: a case study of Nigeria. Singaporean Journal of Business Economics, and Management Studies, Vol.1, no.10, pp.25-34

Tuchman, G. (1978). Images of Women in Mass Media. Oxford University Press.

Ugwuegede, P. (2014). Challenges to women active participation in politics in Nigeria. Sociology and Anthropology, 2(7), pp.284-290. 